\title{
REMEMBERING PROFESSOR JUHAN AUL
}

\author{
MART NikLuS \\ Estonian Naturalists' Society, Tartu
}

In order to provide a somewhat better understanding of the following tribute, let us consider a few facts, as well as events that took place in the former Soviet Union in the recent past.

Having been arrested during a scientific expedition, thrown into Saratov prison on trumped-up accusations, Nikolai Vavilov (1887-1943), the greatest biologist of the $20^{\text {th }}$ century, plant geographer, and geneticist lost his life $[6,1]$.

A few years later, the infamous August 1948 session of the V. I. Lenin AllUnion Agricultural Academy took place in Leningrad (now St. Petersburg). During the session, scientific discussion was replaced by a court hearing on non-conformists [11]. Pseudo-scientific doctrines and ideologies were forced on the participants of the above-mentioned session. "Sages of the wind" and "cudgel critics" [9: 32-34, 44-46, etc.], in other words, those obedient to the regime, were thereafter promoted into leading positions at universities and research institutions. So as not to be deprived of a source of living, some internationally known biologists were forced to change their places of work and specialities. For example, Nikolai Dubinin (1907-1998), a geneticist, after re-qualification, succeeded in the world in his new occupation as an ornithologist no worse than in his earlier speciality [16]. Similar cases could be found among Estonians, as well.

In the middle of the previous century, Tartu State University and Estonian naturalists did not escape "Soviet creative Darwinism" (otherwise known as "Lysenkoist innovations") either [7, 1, 12].

Now, leaving aside the Estonian zoologists (Hans Kauri, Johannes Lepiksaar, et al.) who had fled to the West during World War II and the following occupation and continued working in their particular fields of speciality there, let us focus on Juhan Aul (15 October 1897 - 29 August 1994). He was indeed the grand old man of Estonian zoology and anthropology, who 
was my teacher and the reviewer of my research work in the 1950s, and the person who shaped my world outlook.

The present writer was a student of biology at Tartu State University from 1952-1957 [10]. During those years, the so-called old school scholars (Prof. Johannes Piiper, Prof. Heinrich Riikoja, Lecturer Aliide Lumberg, Assistant Lecturer Salme Aul, et al.) continued working at the Chair of Zoology of the University, located at 46 Vanemuise Street. The programme of lectures or practical training classes taught by them included subjects such as human anatomy, comparative anatomy, invertebrate zoology, general and special ichthyology, etc.

After 1950, the person who no longer came to work and whose name could not be found in the list of staff of the University was Juhan Aul.

Various rumours about his absence circulated among his colleagues and students. Some said that the professor had retired or had been involuntarily sent on pension. Others, however, maintained that, years before, the founder of Estonian anthropology had officially been brought into contempt - allegedly, he had supported or propagated eugenics or even racism.

The Estonian-minded professor, I dare say, was considered sinful and condemned by Michurinists for his exceptional erudition, immoderate command of foreign languages, and for his internationally acclaimed reputation.

Nevertheless, despite dismissal from his earlier employment at the University and the Institute of Zoology and Botany, the professor did not merely sit at home whiling his time away.

In the 1950s, building of dwelling-houses in the town of Tartu, heavily devastated by the war, did not progress at all. In the second largest city of Estonia, there was an unprecedented housing shortage. The University hostels were incredibly crowded: some post-graduate students (now called master's or doctoral students) or other future scientists in the proper meaning of the word were domiciled in a small way behind the cupboard in their respective offices, their sleeping-mattresses spread out on the floor.

At that time, there were no adequate state resources in Tartu as there were in, e.g., Tallinn, Kohtla-Järve, Sillamäe or Narva. Therefore, "the Party and the Government" came to the decision that in Tartu building plots had to be shared out for working people. ${ }^{1}$ Let the inhabitants of Tartu use their own manpower and personal savings to start building private houses at Raadi, Veeriku, Tammelinn, Tähtvere or other suburbs of Tartu. By doing so, these

1 Here and elsewhere, Soviet-style expressions and vocabulary of the period have deliberately been used. 
working people could make use of their leisure time in an advantageous way. Thus, they could produce some surplus value and did not have to wait for years to get a flat in municipal housing (in the so-called "Khrushtchovkas"2).

In contrast to the immigrants who had arrived in Tartu from the East, this chance was eagerly accepted by indigenous Estonians. In the previous years, the Auls lived meagrely in a small flat in my neighbourhood. Our family, too, did not start toiling for the reason that we were better off than most people. The members of the family had to live separately in different parts of the town, and the only hope for us all to get together under one roof was to roll up our sleeves and to start working with a spade.

Under such circumstances, one got to know all the other builders in one's street, and this is probably how I got acquainted with my future neighbour. When we passed our respective building sites in Vikerkaare Street, we greeted each other with the words, "Jõudu tööle!" (approximate translation: "More power to your elbow!"), and often also talked on subjects other than academic. For example, where we could get various building materials that were in short supply at that time, or where we could find a specialist for certain jobs. I learned that my neighbour's relatively spacious stone house had been built from bricks excavated from the ruins of Tartu, and that the masonry had been done by the professor himself. The quality of the work was no worse at all than his typewriting or translation skills. In his opinion, the most troublesome work was plastering of ceilings, and I fully agreed with him. Their new residence became at least twice as big as ours, being surrounded by a large garden. In 1954, six people moved in.

During the years of "enraged condemnation", Salme Aul (19111998), the professor's wife, however, was allowed to continue working at the Chair of Zoology, although with a restricted teaching

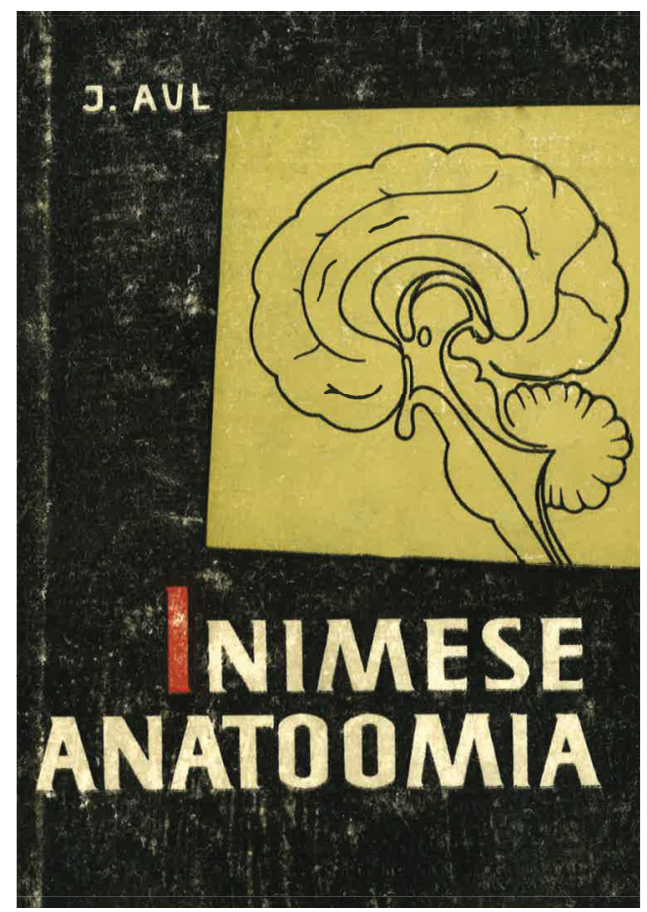

2 Mass-produced low quality flats of standard design during the Soviet period in Estonia. 
load. She gave first-year undergraduate students practical instruction in human anatomy. This subject was then, and still is, obligatory for all biology students, although compared with, e.g., medical students the approach and emphasis may differ. Here I may add that, for most of us, our first acquaintance with Latin vocabulary was through Salme Aul. At the same time, Juhan Aul had already completed the compilation of his textbook of human anatomy for biologists and had already presented it in manuscript form [2]. ${ }^{3}$ Typewritten excerpts from it were circulating in the Vanemuise Street building, too.

Although this scientist and lecturer had been excluded from local academic life for years, a rather objective entry (author unfortunately unknown) concerning his person was published in the Great Soviet Encyclopaedia [15]. ${ }^{4}$ Here it states in black and white that Juhan Aul is an Estonian anthropologist on the staff of Tartu State University. By examination and measuring of more than 25,000 Estonians, he had collected abundant subject matter. A few of his research papers in different languages were referred to there as well.

АУЛЬ, Юхан Миккелевич $($ р. 1897) - эстонский антрополог. Работает в Тартуском государственном университете. А. собрал большой материал по әтнической антропологии әстонцев (обследовано свыше 25000 чел.), показав их близость к другим народам Прибалтики: карелам, финнам, латышам, литовцам, а также к соседнему русскому населению. Кроме того, А. принадлежкат работы по возрастной изменчивости антропологических признаков, по весу тела эстонцев, по описанию черепов и скелетов новокаменного века (неолита) из Арду и Сопе (Эстонская ССР).

C 0 7. A.: A U I J. M., Etude anthropologtque des os. sements humains neolitiques de Sope et d'Ardu. Tartu, 1935; Anthropologische Forschungen in Eest, "Tartu, 1936; Uber die Allersverbnderungen der anthropologischen Werkmale bei Erwachsenen und deren Berticksichtigung in der anthropow logischen Forschung lnezrome Ha pye. ga:: o noapacrubx различия антропологических признаков у взрослых и их Значеним при антропологических исследования ], Tartu, 1941.

3 Here the first words of the Introduction to the above-mentioned textbooks are quoted: Cognosce te ipsum! ("Be familiar with yourself!")

4 More detailed biographical and other information concerning Juhan Aul can naturally be found in Estonian reference books published later on in this country [e.g. 5, 13]. 
The news about the entry in a Russian-language encyclopaedia, consisting of a number of volumes and enjoying mass circulation, quickly spread from mouth to mouth in Tartu. This put cudgel critics, political chameleons, quasi-coryphaei and "builders of the bright future" (lecturers of the so-called scientific communism) in a very awkward situation. Lysenkoism had begun to crack, and suddenly it was discovered (perhaps considering the career of Olga Lepeshinskaya) that what is novel need not always be progressive, that one must have a respectful attitude towards the heritage of the past, etc. The authorities admitted that excessive action had been taken against Juhan Aul, that "an inadvertent error" had been committed with respect to him, and they started to resolve the matter "with discretion". ${ }^{5}$ As of the autumn of 1954, the anthropologist who had been condemned was back at the Chair of Zoology of the University (first as an associate professor, and later as an ordinary professor, consultant professor and emeritus professor) where he was welcomed both by his former colleagues and by the new students. Some of the latter had not even heard of the famous anthropologist before, or of anthropology as a branch of science or a subject.

Juhan Aul was an erudite, a real professional and a brilliant lecturer. He could not be seen consulting any key words or notes during his lectures - everything was spoken from memory. As Moscow did not provide the local University with a syllabus for this particular subject, it was probably drawn up by the professor himself, including its timing schedule. The course, which concluded with an oral examination, comprised 50-60 lecture hours. It covered all aspects of physical anthropology, from anthropogenesis and paleoanthropology to the somatological characteristics of different human races in modern times.

Additionally, students in their last academic years had to take practical studies in anthropology. During such classes, we already looked at one another's morphology and physiognomy with keener attention than we had done before, and with much more informed perception than hitherto. We also learned about the instruments and methods used in anthropological research in former times. Along with the dynamometer and other equipment, our special interest was aroused by the professor's personal "Felix" - a mechanical calculator for performing all the necessary mathematical operations. This was

\footnotetext{
5 Materials concerning the Soviet-style witch-hunt against dissidents and about mental ravishment should be preserved in the University of Tartu Archives and in the University of Tartu History Museum. The author would be grateful, e.g., to any undergraduate student whose course paper or graduation thesis would lay bare the oppression of Prof. Juhan Aul (or of some other lecturer) by the occupation forces in the 1950s. The names of the persons connected with Lysenkoist persecution must be made public.
} 
at the time when Professor Aul and his colleagues started to make use of the abundant anthropological information collected in Estonia in the 1930s. ${ }^{6}$

One of the first items he made clear to us at his lectures was the differentiation between racial science (one of the subdivisions of anthropology) and racism (ideology). He disliked the identification of ethnology with anthropology, which even nowadays is erroneously done - the former, after all, is a social science, but the latter is a natural science. When the subject matter was medical geography, variation statistics, anthropology in practical life, products of garment factories or footwear industry, etc., his humorous examples did not fail to impress. By disregarding the bodily characteristics of the local population, the inappropriately planned output of the above-mentioned factories led to build-up of unsold goods in shops, or the poorly fitting uniforms of conscripts made the public laugh.

Professor Aul's lectures were so captivating that they were constantly attended by Linda Poots (1929-2015), a course auditor who took meticulous notes. She had graduated from Moscow University as a zoologist in 1952, and was later employed for many years as the editor-in-chief of the journal Eesti Loodus (Estonian Nature). Obviously, you can guess why she was so greatly interested in the subject. The notes I took and the drawings I made sixty years ago have also been preserved for eventual future use.

Professor Aul recommenced his work in his Alma Mater probably with a full load in his speciality. The professor's academic tasks included some special chapters of zoology (e.g. theriology), lectures on comparative anatomy, seminars in zoology and the so-called enlarged practical training (suur praktikum). From the seminars, I still remember my report "Methods and Principles of Systematic Zoology" (based on the book by Ernst Mayr, E. Gorton Linsley and Robert L. Usinger), followed by discussion. During the thorough practical training, we learned, for instance, how to make resistant slides in histology, etc. If we had had any fitting specimens and tools at hand, we could have even been able to cope with taxidermy.

Prof. Aul was not particularly enthusiastic about ornithology. Nonetheless, while analyzing and reviewing my graduation thesis on the subject, his conclusion was that the research paper ( $242 \mathrm{pp}$.) had been written "in fluent and easily readable language" and its author had become "an experienced ornithologist". Naturally, the professor could not have foreseen that in the following year the

6 The study was crowned by the monograph "Антропология эстонцев /Anthropologia estonica/" [3]. The book was carefully read, even in the GULAG. 
author of the paper would be sent to "the higher school of life" (to the Russian GULAG)...

He was convinced that any top scientist should be competent in his own speciality, human psychology and university didactics. This meant that visual aids should be used at lectures and seminars, the wording should be logical and linguistically correct - that the presented subject should be comprehensible to ordinary people. On the other hand, any university graduate whom the appointment board (the so-called slave market) had sent to teach natural history at a village school had, in addition to giving lessons, certainly to be able to arrange research work among the pupils, to superintend and guide the most active of them.

It is also worth mentioning that since 1959, under the initiative of Prof. Juhan Aul, conferences of naturalists started to be arranged at Tartu State University. There is no doubt that the impetus greatly came from his own past. In the years of his youth (when his name was still Johann Klein) Juhan Aul had even taught the Estonian language at school. After obtaining a professorship, he participated in terminology commissions and compiled glossaries for specialists [4].

Naturally, Prof. Aul was an interesting interlocutor. However, as nearly all the lecturers of natural sciences during the socalled period of stagnation, he avoided exchange of ideas which did not concern his speciality. Mrs. Salme Aul was even more cautious in this respect. But neither of them concealed their delight when, in the summer of 1966, I returned alive from my first political imprisonment to the more or less civilized surroundings in my native land.

Professor Juhan Aul retained his erudition and ability to work until the end of his life.

On his last journey, he was interred at Raadi Cemetery in Tartu on 2 September 1994. In

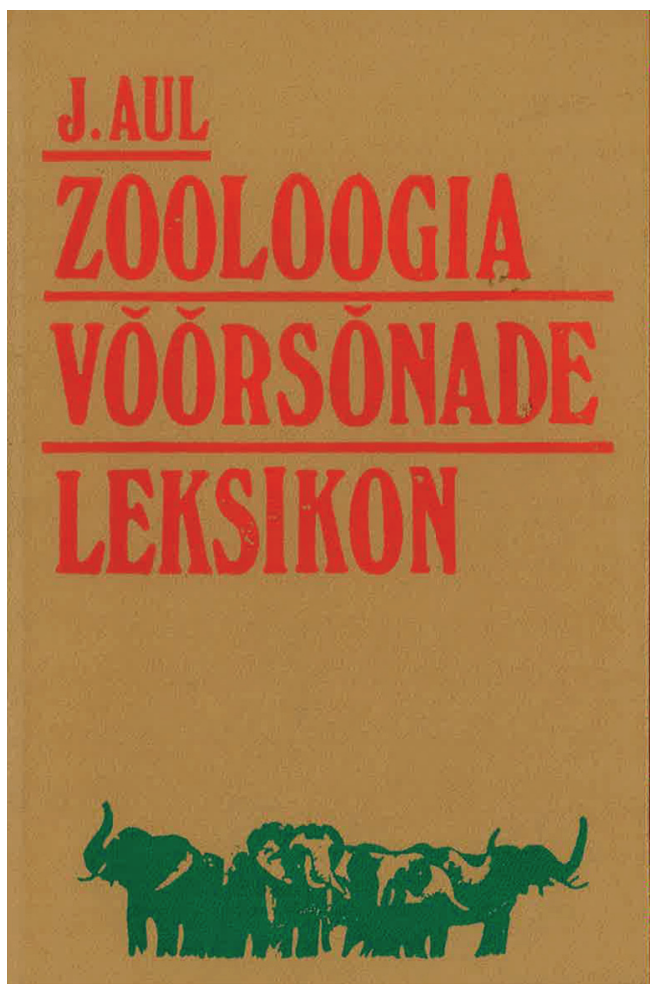


post-war Estonia, this scientist had become the educator of an entire generation of anthropologists. Among his academic disciples of greater renown, Karin Mark (1922-1999), Helje Kaarma (1933) and Leiu Heapost (1936) should be mentioned here. In February 2016, the latter was awarded the White Star Order (Class V) by Toomas Hendrik Ilves, President of the Republic of Estonia.

Whether this very world be big or small, wondrous cases happen here time and again.

In the 1960s, being imprisoned in a Mordovian labour camp for political prisoners, I got acquainted with Bruno Javoiš (1941), a former inhabitant of Riga who did not know a single word of Estonian at that time. After being released from captivity and having resettled in Tartu, he married Aina, the daughter of the Auls, thus becoming their son-in-law. Later, as an extra-mural student, this Latvian man graduated from Tartu State University. Subsequently, for a number of years, he was employed as a history teacher for Estonian pupils at Jõgeva Upper Secondary School (Gümnaasium). He was the interpreter for Valdis Zatlers, President of the Republic of Latvia, during an Estonian-Latvian joint event in the Latvian town of Cēsis in 2009. His son Juhan Javoiš (1975) [8] is a zoology graduate from the University of Tartu and one of the editors of the journal Eesti Loodus. Can it be genetics? Eugenics? Or atavism?

The biography of Juhan Aul offers a graphic example of a country lad from Pärivere Village in Pärnu County who, owing to his talent, industriousness and exceptional willpower, per aspera ad astra, regardless of different social orders, became a top scientist of whom the Estonian people may be proud. Considering the non-objectivity and tendentiousness of post-Soviet Estonian value assessments, it really takes my breath away when the list of prominent Estonian figures of the $20^{\text {th }}$ century includes political chameleons, half-educated upstarts, and even agents of the $\mathrm{KGB}^{7}$ - but not the winner of the Karl Ernst von Baer Award (1976), Recipient of Tartu State University Memorial Medal (1982), Honorary Member of the Estonian Naturalists' Society (1967), and the founder or active member of various Estonian or foreign research institutions.

Since autumn 1995, Juhan Aul Days have been arranged by the Centre for Physical Anthropology at the Faculty of Medicine of the University of Tartu and the Estonian Naturalists' Society. Papers on Anthropology are regularly published in English. As a personality and teacher, Prof. Juhan Aul has always

7 KGB - Комитет государственной безопасности (State Security Committee) organization of intelligence service and terrorism of the GESTAPO-type in Soviet-occupied Estonia. 
been a grand example for the author. He has made an unforgettable impression on me.

In closing: I extend a warm expression of gratitude to my friendly nextdoor neighbours, to Juhan Aul's relatives, as well as to Mrs. Ulje Natus, librarian of the Estonian Naturalists' Society, for the additional information provided by them that I used in the present essay. My heartfelt thanks go to my colleagues Mr. Terry Oatley (Republic of South Africa), Mr. John F. Burton (Great Britain) and Mr. Ilmar Anvelt (University of Tartu) for their linguistic advice and corrections.

\section{REFERENCES}

1. Aleksandrov V. (1988). Nõukogude bioloogia rängad aastad (translated by M. Viikmaa). Eesti Loodus, 7, 460-463; 8, 525-531, 11, (724-727).

2. Aul J. (1962, second, revised edition 1976). Inimese anatoomia. Õpik bioloogidele. Tallinn. 435 pp. (1962), 359 pp (1976).

3. Aul J. (1964). Антропология эстонцев /Anthropologia estonica. Tartu. 387 pp.

4. Aul J. (1978). Zooloogia võõrsõnade leksikon. Tallinn. 192 pp.

5. Eesti Entsüklopeedia (2000). Vol. 14 (Eesti elulood), 28-29.

6. Eilart J. (1965). Veendumustest ei taganeta. Sirp ja Vasar, 1.01.1965.

7. Haberman H. (1961). Materialismi ja idealismi võitlusest bioloogias. Tallinn. $47 \mathrm{pp}$.

8. Javoiš J. (2008). Juhan Aul 111 - kas unistused luhtusid? Eesti Loodus, 10, $42-46$.

9. Kangilaski O. (1968). Jutulõng. (Loomingu Raamatukogu, 30).

10. Kukk T. (2015). Darwini tundmine aitab igas olukorras (an interview). Eesti Loodus, 5, 34-38.

11. Olukorrast bioloogiateaduses (1948). Tartu. $540 \mathrm{pp}$.

12. Parmasto E. (1988). See kurikuulus augustisessioon. Eesti Loodus, 11, 728-730.

13. TEA Entsüklopeedia (2009). Vol. 3, 123.

14. Vavilov N. (1967). Viis kontinenti. (Translation from Russian and foreword by J. Eilart). Tallinn.

15. Большая Советская Энциклопедия [Bolšsaja Sovetskaja Ėnciklopedija], 1950, т. 3, стр. 481.

16. Дубинин Н.П. [Dubinin N.P.] (1975). Вечное движение [Večnoe dviženie]. Москва [Moskva].

\section{Address for correspondence:}

Mart Niklus

E-mail: martniklus@gmail.com 